\title{
Checklist of Caddisflies (Insecta, Trichoptera) from Mato Grosso do Sul State, Brazil
}

\author{
Adolfo R. Calor ${ }^{1}$ \& Fabio B. Quinteiro ${ }^{1,2}$
}

\begin{abstract}
1. Laboratório de Entomologia Aquática, PPG Diversidade Animal, Instituto de Biologia, Universidade Federal da Bahia, Rua Barão de Geremoabo, 147, Campus Ondina, 40170-290 Salvador, BA, Brazil. (acalor@gmail.com)

2. Laboratório de Biologia Comparada e Abelhas, Departamento de Biologia, FFCLRP, Universidade de São Paulo, Av. dos Bandeirantes, 3900 , Monte Alegre,
\end{abstract} 14040-901 Ribeirão Preto, SP, Brazil.

Received 24 November 2016

Accepted 6 February 2017

DOI: $10.1590 / 1678-4766 e 2017149$

\begin{abstract}
Trichoptera presents about 15,000 species described globally, of which 2,562 are recorded in the Neotropics and 642 in Brazil, distributed in 70 genera and 16 families. In Brazil, knowledge of the distribution and species richness of Trichoptera is incipient and heterogeneous, especially in some states such as Mato Grosso do Sul. In this work, we present an updated checklist of caddisflies for Mato Grosso do Sul state, representing nine families, 24 genera, and 16 species, four of them are new species records. Additionally, a new record of species for the Brazilian country is presented.
\end{abstract}

KEYWORDS. Aquatic insects, caddisfly, new records, distribution, Biota-MS Program.

RESUMO. Lista dos tricópteros (Insecta, Trichoptera) do estado do Mato Grosso do Sul, Brasil. A ordem Trichoptera possui aproximadamente 15.000 espécies descritas no mundo, dentre as quais 2.562 possuem registro na Região Neotropical e 642 delas no Brasil, distribuídas em 70 gêneros e 16 famílias. No Brasil, o conhecimento de distribuição e riqueza de espécies de Trichoptera é incipiente e heterogêneo, principalmente em alguns estados, como o Mato Grosso do Sul. Nesse trabalho, apresentamos uma checklist atualizada dos tricópteros do estado do Mato Grosso do Sul, representando nove famílias, 24 gêneros e 16 espécies, destas quatro são novos registros para o estado. Adicionalmente, é apresentado um novo registro de espécie para o Brasil.

PALAVRAS-CHAVE. Distribuição, insetos aquáticos, novos registros, tricópteros, Programa Biota-MS.

Caddisflies (Trichoptera) constitute the most diverse clade of exclusively aquatic insects, recording about 15,000 described species worldwide (Holzenthal et al., 2011), of which 2,562 occur in the Neotropical region (Morse, 2011) and 619 in Brazil, distributed in 70 genera and 16 families (SANTos et al., 2015).

Since the first checklist of Brazilian caddisflies, the numbers of species and distribution records have increased exponentially. PAPROCKI et al. (2004) reported only 378 species in 61 genera, and SANTOS et al. (2015) elevated it 642 species and 70 genera. In last decades, some publications on distributional notes or regional checklists are were published (e.g., BlahniK et al., 2004; Dumas et al., 2010; CALOR, 2011; Nogueira \& CABETte, 2011; Costa et al., 2014; Quinteiro et al., 2014) and around 100 new species were described from Brazil, but there are at least another 300 new species to be described, deposited in museums (CALOR, 2011). Despite the increase of knowledge of Brazilian caddisflies, the records were especially concentrated in Southeastern and Northern regions (related to the location of traditional research groups on aquatic insects). Therefore, some species have "fragmented" distribution (probably due to some states with no survey yet) and others have punctual distribution (only known from holotype locality). In this way, although there is still a big number of undescribed species, the known species present geographical distributions poorly understood, with many record gaps leading to an unreal disjunct distribution. Thus, Linnean and Wallacean shortfalls (LomoLINo, 2004; WHITTAKER et al., 2005) were not overcome yet. Additionally, two other subjects draw attention: the cited increase of knowledge was based especially on adults, and the majority of taxa were described without a phylogenetic approach. As the knowledge of the caddisflies immature stages is around $2 \%$ only (Holzenthal, 2004) and these aquatic stages are very useful to monitoring programs of water quality, there is a new case of shortfall, named here as Müllerian shortfall, in reference to Fritz Müller, a dedicated naturalist who sought to understand more of the immature stages of caddisflies.

The purpose of this paper is to continue the formal documentation of Brazilian caddisflies based on material obtained from Mato Grosso do Sul State to minimize the shortfalls and consequently to collaborate with the database on biodiversity of state, as part of the goals of BIOTA-MS. 


\section{MATERIAL AND METHODS}

Study area. The state of Mato Grosso do Sul (17 to $24^{\circ} \mathrm{S}, 51^{\circ}$ to $58^{\circ} \mathrm{W}$ ) encompass about $4.2 \%$ of the Brazilian territory (CÁCERES et al., 2008). The state is considered by some authors a transitional area due the presence of at least three major biomes: Cerrado in the center and northeastern regions, Atlantic Forest in the southern and eastern regions and Pantanal in the northwestern region (CÁCERES et al., 2008). These biomes are composed by decidual and semidecidual forests. The climate is considered tropical in the state, but it tends to subtropical in the southern portion (CÁCERES et al., 2008). The rainfall is about 1,250 to $1,500 \mathrm{~mm}$ during the months of October to March, being the remaining months the dry season (CÁCERES et al., 2008). Moreover, it is a frontier land with Bolivia and Paraguay, which implies that part of the fauna may be shared among Mato Grosso do Sul and these countries.

Sampling. The checklist was based on the literature (Flint et al., 1999; PAPRocki et al., 2004; SANTOS et al., 2015; Costa et al., 2014; QuinTEIro et al., 2014); examined material from Museu de Zoologia da Universidade de São Paulo (MZSP), and Museu de Zoologia da Universidade Federal da Bahia, Collection of Aquatic Insects (UFBA). The specimens were collected using entomological nets, and the light pan traps (CALOR \& MARIANO, 2012). Specimens were fixed and preserved in $80 \%$ ethanol. The species were identified by comparison with other identified specimens and primary literature. The collected material was deposited in the Museu de Zoologia da Universidade Federal da Bahia (UFBA), Salvador, BA, Brazil. Additional genera records were based on the literature as cited in the Additional genera gecords section.

Acronyms for the Brazilian States are the following: Acre (AC), Alagoas (AL), Amazonas (AM), Amapá (AP), Bahia (BA), Ceará (CE), Goiás (GO), Espírito Santo (ES), Maranhão (MA), Mato Grosso (MT), Mato Grosso do Sul (MS), Minas Gerais (MG), Pará (PA), Paraíba (PB), Paraná (PR), Pernambuco (PE), Piauí (PI), Rio de Janeiro (RJ), Rio Grande do Norte (RN), Rio Grande do Sul (RS), Rondônia (RO), Roraima (RR), Santa Catarina (SC) and São Paulo (SP), Sergipe (SE), Tocantins (TO).

\section{RESULTS AND DISCUSSION}

Sixteen species of caddisflies were recorded in Mato Grosso do Sul distributed in five families (Calamoceratidae, Hydropsychidae, Leptoceridae, Odontoceridae, and Polycentropodidae), and six genera (Cyrnellus, Leptonema, Marilia, Oecetis, Phylloicus, and Smicridea) (Tab. I). Four new records of species (Phylloicus angustior, P. lituratus, Leptonema viridianum, Smicridea mangaratiba), three new records of genera, and one new record to family (Calamoceratidae) are provided to state of Mato Grosso do Sul. Additionally, a new species record for Brazil is also presented.
Tab. I. Species record distribution of Trichoptera by state in Brazil. The state of Mato Grosso do Sul is in bold [modified PAPROCKI et al. (2004) and SANTOS et al. (2014)]. Updated numbers consider the total number of species presented by SANTOS et al. (2015), Costa et al. (2015), QuinteIro et al. (2014), PAProcki \& FranCA (2014), Quinteiro \& CALOR (2015), plus the new records. *Total number of Brazilian caddisflies species considering the data from SANTos et al. (2015) plus five species (Atanatolica bonita Costa \& Calor, 2014; Macrostemum bravoi Franca, Paprocki \& Calor, 2013; Macrostemum nigrum Franca, Paprocki \& Calor, 2013; Smicridea mangaratiba Almeida \& Flint, 2002).

\begin{tabular}{|c|c|c|c|}
\hline $\begin{array}{l}\text { Brazilian } \\
\text { State }\end{array}$ & $\begin{array}{l}\text { PAPROCKI et al. } \\
\text { (2004) }\end{array}$ & $\begin{array}{l}\text { SANTOS et al. } \\
\quad(2015)\end{array}$ & $\begin{array}{l}\text { Updated } \\
\text { checklist }\end{array}$ \\
\hline $\mathrm{AC}$ & 0 & 1 & 5 \\
\hline $\mathrm{AL}$ & 0 & 0 & 0 \\
\hline $\mathrm{AM}$ & 109 & 175 & 176 \\
\hline $\mathrm{AP}$ & 0 & 1 & 1 \\
\hline BA & 8 & 40 & 54 \\
\hline $\mathrm{CE}$ & 1 & 12 & 12 \\
\hline DF & 8 & - & 8 \\
\hline ES & 12 & 53 & 53 \\
\hline GO & 11 & 17 & 17 \\
\hline MA & 0 & 1 & 0 \\
\hline MG & 101 & 177 & 178 \\
\hline MS & 3 & 11 & 16 \\
\hline MT & 8 & 24 & 26 \\
\hline PA & 54 & 78 & 78 \\
\hline PB & 1 & 4 & 6 \\
\hline PE & 0 & 29 & 31 \\
\hline PI & 0 & 2 & 2 \\
\hline PR & 55 & 71 & 71 \\
\hline RJ & 76 & 160 & 161 \\
\hline $\mathrm{RN}$ & 0 & 0 & 1 \\
\hline RO & 14 & 18 & 19 \\
\hline $\mathrm{RR}$ & 17 & 21 & 21 \\
\hline $\mathrm{RS}$ & 4 & 4 & 4 \\
\hline $\mathrm{SC}$ & 97 & 121 & 121 \\
\hline SE & 0 & 1 & 1 \\
\hline SP & 69 & 130 & 132 \\
\hline TO & 0 & 0 & 0 \\
\hline Brazil & 378 & 642 & $643 *$ \\
\hline
\end{tabular}

\section{Checklist of Caddisflies from Mato Grosso do Sul State}

\section{CALAMOCERATIDAE Phylloicus angustior Ulmer, 1905}

Type locality: Brazil, Rio Grande do Sul. Material examined: Brazil, Mato Grosso do Sul: Bonito, Gruta Azul road, Rio Seco, 2101'51'S, 56 37'25'W, 480 m, 24.vi.2009, light trap, Lecci, L., Schulz, G., Stefin, G., $2{ }^{\top}$. Distribution: Argentina, Brazil (GO, MG, MS, PR, RS, SC), Colombia, Paraguay, Uruguay, Venezuela.

\section{Phylloicus lituratus Banks, 1920}

Type locality: Colombia, Mariquito. Material examined: Brazil, Mato Grosso do Sul: Bonito, Fazenda Pitangueiras, Córrego Pitangueiras, 2052'03”'S, $56^{\circ} 35^{\prime} 24^{\prime \prime} \mathrm{W}, 463 \mathrm{~m}, 23 . v i .2009$, entomological net, Lecci, L., Schulz, G., Stefin, G., Ô; Rondônia: Campo Novo de Rondônia, Linha C9, Poço do Marimbondo, 
10³5'26”S, 6328'15.5”W, Malaise 39, $246 \mathrm{~m}, 23$ 25.v.2012, Urso-Guimarães \& eq. Col. Distribution: Brazil (MS, RO), Colombia, Costa Rica, Nicaragua, Panama and Venezuela.

Notes: This species had records in Colombia, Costa Rica, Nicaragua, Panama and Venezuela (PRATHER, 2003). It is the first record of this species for Brazil.

\section{HYDROPSYCHDAE Leptonema aspersum (Ulmer, 1907)}

Type locality: Brazil, Santa Rita (in Neoleptonema). Distribution: Brazil (BA, MS), Guyana, Surinam, Venezuela.

\section{Leptonema columbianum Ulmer, 1905}

Type locality: Brazil, Santa Rita. Distribution: Argentina, Bolivia, Brazil (RO, AM, PA, BA, MG, SP, MS, GO, DF), Colombia, Guyana, Paraguay, Peru, Surinam, Venezuela.

\section{Leptonema viridianum Navás, 1916}

Type locality: Brazil, Bahia. Material examined: Brazil, Mato Grosso do Sul: Costa Rica, Rio Sucuriú, 1859'03’S, $53^{\circ} 10^{\prime} 10^{\prime \prime} \mathrm{W}, 02 . x i .2004$, light trap, Froehlich, O., $\sigma^{\jmath}$, 2․ Distribution: Argentina, Bolivia, Brazil (DF, ES, GO, MG, PA, RJ, MS), Colombia, Ecuador, Guyana, Paraguay, Peru, Venezuela.

\section{Smicridea (Rhyacophylax) mangaratiba Almeida \& Flint, 2002}

Type locality: Brazil, Rio de Janeiro: Mangaratiba. Material examined: Brazil, Mato Grosso do Sul: Costa Rica, Rio Sucuriú, 18 59'03”S, 5310'00”W, 02.xi.2004, light trap, Froehlich, O., $33 \mathrm{O}^{\mathrm{N}}, 21$ ․ Distribution. Brazil (RJ, MS).

\section{LEPTOCERIDAE Oecetis amazonica (Banks, 1924)}

Type locality: Brazil, Manaus (in Oecetina). Material examined: Brazil, Mato Grosso do Sul: Serra da Bodoquena, Acampamento Adventista, 30.vii.2006, Froehlich, O., ô, ․ Distribution: Argentina, Bolivia, Brazil (AM, MS), Peru, Venezuela.

\section{Oecetis angelae Henriques-Oliveira, Dumas \& Nessimian, 2014}

Type locality: Brazil, Mato Grosso do Sul, Ladário. Distribution: Brazil (MS).

\section{Oecetis dominguezi Rueda-Martín, Gibon \& Molina, 2011}

Type locality: Bolivia, Beni, Lake Colorada. Distribution. Bolivia, Brazil (MS).

\section{Oecetis excisa Ulmer, 1907}

Type locality: Argentina, Chaco de Santa Fé, Las Garzas. Material examined: Brazil, Mato Grosso do Sul, Serra da Bodoquena, Acampamento Adventista, 30.vii.2006, Froehlich, O., 3ڤึ, 2 ㅇ․

Distribution: Argentina, Bolivia, Brazil (BA, CE, GO, MS, PA, PE, SP), Mexico, Paraguay, Venezuela.

\section{Oecetis paranensis Flint, 1982}

Type locality: Argentina, Chaco, Riacho Barranqueras, Puerto Vilelas. Distribution: Argentina, Bolivia, Brazil (BA, MG, MS, PE), Paraguay, Peru.

\section{ODONTOCERIDAE Marilia lateralis Flint, 1983}

Type locality: Paraguay, Dpto. San Pedro, arroyo Tapiracuay, San Estanislao. Distribution. Brazil (MS), Colombia, Paraguay, Uruguay.

\section{POLYCENTROPODIDAE Cyrnellus arotron Flint, 1971}

Type locality: Brazil, Pará, Rio Tocantins. Distribution: Argentina, Brazil (AM, MS, PA), Uruguay.

\section{Cyrnellus bifidus Flint, 1971}

Type locality: Brazil, Amazonas, Paraná do Careiro, Divinópolis. Distribution. Argentina, Brazil (AM, MS).

\section{Cyrnellus fraternus (Banks, 1905)}

Type locality: United States, Maryland, Plummer's Island (Cyrnus). Distribution: Argentina, Brazil (AM, BA, ES, MG, MS, MT, PA, PR, SC), Costa Rica, Ecuador, El Salvador, Mexico, Nicaragua, Panama, Paraguay, Surinam, Uruguay, United States, and Venezuela.

\section{Cyrnellus mammillatus Flint, 1971}

Type locality: Brazil, Amazonas, Lago des Rio Luna am oberen Teil. Distribution: Argentina, Brazil (AM, MG, MS, PA, PR, RJ, SP), Ecuador, Paraguay, Peru, and Uruguay.

Additional genera records. Some ecological studies recorded caddisflies from state of Mato do Grosso do Sul, but the taxonomic resolution is only until the generic level, as Souza-Franco et al. (2009) and Righi-CAVALlaro et al. (2010). SouZA-FrANCO et al. (2009), in a study focusing on characterization of the aquatic insect community associated to Eichhornia azurea, presented three caddisfly genera, one genus of Hydropilidae (Oxyethira Eaton, 1873), one of Polycentropodidae (Polycentropus Curtis, 1835), and an 
undetermined genus of Hydropsychidae. Posteriorly, RiGHICAVAllaro et al. (2010) presented an inventory of immature EPT in Miranda River basin with 22 caddisfly genera in nine families: Phylloicus (Calamoceratidae), Austrotinodes Schmid, 1955 (Ecnomidae), Itauara Müller, 1888, Protoptila Banks, 1904, Mortoniella Ulmer, 1906 (Glossosomatidae), Helichopsyche Siebold, 1856 (Helicopsychidae), Blepharopus Kolenati, 1859, Leptonema, Macromema Pictet, 1836, Smicridea (Hydropsychidae), Abtrichia Mosely, 1939, Hydroptila Dalman, 1819, Neotrichia Morton, 1905, Oxyethira (Hydroptilidae), Nectopsyche Müller, 1879, Oecetis, Triplectides Kolenati, 1859, and undetermined genus (Leptoceridae), Chimarra Stephens, 1829 (Philopotamidae), Cernotina Ross, 1938, Cyrnellus, Polyplectropus Ulmer, 1905 (Polycentropodidae). So far, the known recorded caddisfly diversity for Mato Grosso do Sul is represented by 16 species in nine families and 24 genera, being five of then new species records, including a new record for the country. Considering the reduced collect effort of caddisflies in Mato Grosso do Sul State, the natural conditions, and the difference between the number of recorded species (16 from six genera) and the records of the genera (24), we can have a close estimate of the huge challenge to the next years.

Main research groups. Laboratório de Biologia Aquática, UNESP, campus Assis, headed by Dr. Pitágoras da Conceição Bispo; Laboratório de Citotaxonomia e Insetos Aquáticos, INPA, headed by Dr. Neusa Hamada and colaboration of Dr. Ana Maria de Oliveira Pes; Laboratório de Diversidade de Insetos Aquáticos, Centro Universitario Norte do Espirito Santo, Universidade Federal do Espirito Santo, headed by Dr. Frederico Falcão Salles; Laboratório de Diversidade de Insetos Aquáticos, Departamento de Ecologia e Zoologia, Universidade Federal de Santa Catarina, headed by Dr. Luiz Carlos de Pinho; Laboratório de Ecologia de Insetos, Departamento de Biologia Geral, Instituto de Ciências Biológicas, Universidade Federal de Goiás, headed by Dr. Adriano Sanches Melo; Laboratório de Entomologia Aquática, Departamento de Biologia, Faculdade de Filosofia Ciências e Letras de Ribeirão Preto, Universidade de São Paulo, headed by Dr. Claudio Gilberto Froehlich; Laboratório de Entomologia Aquática, Departamento de Hidrobiologia, Universidade Federal de São Carlos, headed by Dr. Suzana Trivinho Strixino and Dr. Alaide Aparecida Fonseca Gessner; Laboratório de Entomologia Aquática, Departamento de Zoologia, Instituto de Biologia, Universidade Federal da Bahia, headed by Dr. Adolfo Ricardo Calor; Laboratório de Entomologia, Instituto de Ciências Naturais e Tecnológicas, Universidade do Estado do Mato Grosso, headed by Dr. Helena Soares Ramos Cabette; Laboratório de Entomologia, Universidade Federal do Rio de Janeiro, headed by Dr. Jorge Luiz Nessimian; Laboratório de Invertebrados, Museu de História Natural, Pontifícia Universidade Católica de Minas Gerais, headed by Dr. Henrique Paprocki; Laboratório de Limnologia, Departamento de Biologia Geral, Instituto de Ciências Biológicas, Universidade Federal de Goiás, headed by Dr. Leandro Gonçalves de Oliveira; Laboratório de Organismos Aquáticos, Departamento de Ciências Biológicas, Universidade Estadual de Santa Cruz, headed by Dr. Rodolfo Mariano.

Main collections in Brazil. Museu de Zoologia, Universidade de São Paulo (MZUSP); Museu Nacional, Universidade Federal do Rio de Janeiro (MNRJ); Museu de Zoologia, Universidade Federal da Bahia (UFBA); Instituto Nacional de Pesquisas da Amazônia (INPA); Collection Padre Jesus Santiago Moure, Universidade Federal do Paraná (DZUP); Entomological Collection Professor José Alfredo Pinheiro Dutra, Departamento de Zoologia from Universidade Federal do Rio de Janeiro (DZRJ). Outside the country, there are great collections and among them some are very representative and worth to mention like the National Museum of Natural History, Washington, D.C., USA (NMNH), University of Minnesota Insect Collection, Saint Paul, Minnesota, USA (UMSP), and the Insect Collection of the British Museum of Natural History, London, England (BMNH).

Main knowledge gaps. Despite the increase of knowledge provided by the results presented herein, the knowledge on caddisflies in the state of Mato Grosso do Sul still remains scarce. There are just a few collection sites already sampled in the state. Moreover, the knowledge of ecology, physiology and a more accurate distribution of the species recorded in the state remain unknown. In this way, new collecting expeditions should be made in attempt to provide more information. It will refine our knowledge of the species distribution, relationships and biology, providing a better understand of the fauna in the state and, consequently, for the Brazilian fauna. It will be central for efficient conservation politics even in a national level.

An outlook for the next 10 years. The number of taxonomists working on caddisflies in Brazil has increased significantly (CALOR, 2011). Our knowledge has been improved in the same proportion. One of the main factors these increase can be attributed to, is the spread of aquatic insects research groups in diverse Brazilian regions previously devoid of this specific research. The taxonomic knowledge on caddisflies must be increased exponentially in the next years in order to enable a more precise use of these data to solve other questions, such as the biomonitoring of aquatic ecosystems. This way, it is expected that, not only the taxonomic knowledge on Trichoptera will grow in the near future, but also other scientific fields associated to it.

Acknowledgements. We are grateful to Fundação de Apoio ao Desenvolvimento do Ensino, Ciências e Tecnologia do Estado de Mato Grosso do Sul (Fundect) and Superintendência de Ciências e Tecnologia do Estado de Mato Grosso do Sul (Sucitec/MS) for the invitation to participate in this special issue of Iheringia, Série Zoologia and financial support for publication. To Dr. Fabio de Oliveira Roque (UFMS, Biota-MS Program) to encourage this manuscript and donation of specimens, and Ms Lucas Lecci, Rafael Moretto, and Dalton Amorim (USP) for donation of specimens. This article was financially supported by CNPq fellowships (grants \# 243238/2014, 503285/2009-9, 142211/2012-5). 


\section{REFERENCES}

Blahnik, R. J.; Paprocki, H. \& Holzenthal, R. W. 2004. New distribution and species records of Trichoptera from Southern and Southeastern Brazil. Biota Neotropica 4:1-6.

Cáceres, N. C.; Carmignotto, A. P.; Fischer, E. \& Santos, C. F. 2008. Mammals from Mato Grosso do Sul, Brazil. Check List 4(3):321-335.

CAlor, A. R. 2011. Checklist dos Trichoptera (Insecta) do Estado de São Paulo, Brasil. Biota Neotropica 11(1a):1-12.

Calor, A. R. \& Mariano, R. 2012. UV Light Pan traps for Collecting Aquatic Insects. EntomoBrasilis 5(2):164-166.

Costa, A. M. \& CAlor, A. R. 2014. A new species of Atanatolica Mosely 1936 (Trichoptera: Leptoceridae) from Serra Bonita, Bahia, Brazil. Zootaxa 3790(1):194-200.

Costa, A. M.; Quinteiro, F. B. \& Calor, A. R. 2014. Trichoptera do Semiárido I: Annulipalpia. Cap. 17. In: Bravo, F. \& CAlor A. R. eds. Artrópodes do Semiárido: biodiversidade e conservação. Feira de Santana, Printmídia, p. 215-228

Dumas, L. L.; Santos, A. P. M.; Jardim, G. A.; Ferreira Jr, N. \& Nessimian, J. L. 2010. Insecta Trichoptera: New records from Brazil and other distributional notes. Check List 6(1):7-9.

Flint, O. S. JR; Holzenthal, R. W. \& Harris, S. C. 1999. Catalog of the Neotropical Caddisflies (Insecta: Trichoptera). Columbus, Ohio Biological Survey. 239p.

Holzenthal, R. W. 2004. Rearing Trichoptera. Nectopsyche: Neotropical Trichoptera Newsletter, p. 6. Available at: $<$ http//:www.entomology. umn.edu/museum/links/Nectopsyche_2.pdf $>$. Accessed in 28 January 2013.

Holzenthal, R. W.; Morse. J. C. \& KJer, K. M. 2011. Order Trichoptera Kirby, 1813. In: Animal biodiversity: An outline of higher-level classification and survey of taxonomic richness (Z.Q. ZHANG. ed.). Zootaxa 3148:209-211.

Lomolino, M. V. 2004. Conservation biogeography. In: Lomolino, M. V. \& Heaney, L. R. eds. Frontiers of Biogeography. New directions in the geography of nature. Massachusetts, Sinauer Associates, Sunderland, p. 293-296.
Morse, J. C. 2011. The Trichoptera World Checklist. Zoosymposia 5:372380.

Nogueira, D. S. \& CABETTE, H. S. R. 2011. Novos registros e notas sobre distribuição geográfica de Trichoptera Kirby, 1813 (Insecta) do Estado de Mato Grosso, Brasil. Biota Neotropica 11(2):347-355.

PAProcki, H. \& FrançA, D. 2014. Brazilian Trichoptera Checklist II. Biodiversity Data Journal 2 (e1557):1-109.

Paprocki, H.; Holzenthal, R. W. \& BlahniK, R. J. 2004. Checklist of the Trichoptera (Insecta) of Brazil I. Biota Neotropica 4(1):1-22.

Prather, A. L. 2003. Revision of the Neotropical caddisfly genus Phylloicus (Trichoptera: Calamoceratidae). Zootaxa 275:1-214.

Quinteiro, F. B. \& CAlor, A. R. 2015. A Review of the Genus Oecetis (Trichoptera: Leptoceridae) in the Northeastern Region of Brazil with the Description of 5 New Species. PLoS ONE 10(6): e0127357. doi:10.1371/journal.pone.0127357

Quinteiro, F. B.; Costa, A. M. \& Calor, A. R. 2014. Trichoptera do Semiárido II: Integripalpia. Cap. 18. In: Bravo, F. \& CAlor, A. R. eds. Artrópodes do Semiárido: biodiversidade e conservação. Feira de Santana, Printmídia, p. 229-244.

Righi-Cavallaro, K. O.; Spies, M. R. \& Siegloch, A. E. 2010. Ephemeroptera, Plecoptera and Trichoptera assemblages in Miranda River basin, Mato Grosso do Sul State, Brazil. Biota Neotropica 10(2):253-260.

Santos, A. P. M.; Dumas, L. L.; Jardim, G. A.; Silva, A. L. R \& Nessimian, J. L. 2015. Brazilian Caddisflies: Checklists and Bibliography. Avaiable at: <https://sites.google.com/site/braziliancaddisflies $>$. Access in 13 July 2014.

Souza-Franco, G. M.; Andrian, L. F. \& Franco, R. M. 2009. Comunidade de insetos aquáticos associados à Eichhornia azurea (Schwartz) Kunth em uma lagoa de várzea na planície de inundação do Alto Rio Paraná, Mato Grosso do Sul, MS, Brasil. Biológico 71(1):83-91.

Whittaker, R. J.; Araújo, M. B.; Paul, J.; Ladle, R. J.; Watson, J. E. M. \& WiLlis, K. J. 2005. Conservation biogeography: assessment and prospect. Diversity and Distributions 11:3-23. 